\title{
«СЕРГЕЙ ИВАНЫЧ»: ОБ ОДНОМ «ГЕРОЕ» МАНДЕЛЬШТАМОВСКОГО «ШУМА ВРЕМЕНИ»
}

\author{
А. Г. Мец \\ (С.-Петербург)
}

Яркая и увлекательная автобиографическая проза О. Э. Мандельштама «Шум времени», написанная в 1923-1924 гг., была и остается одним из центров внимания читателей и исследователей вплоть до настоящего времени. Одна из наиболее интригующих главок ее получила название «Сергей Иваныч» - по имениотчеству персонажа, который в ней описан. Время действия начало Революции 1905 года. «Сергей Иваныч» взят репетитором к юному Мандельштаму, а с другой стороны вовлечен в бурные революционные события. С изрядной долей иронии (окрасившей все главы его книжки), Мандельштам пишет:

Конечно, Сергей Иваныч не был революционером. Да останется за ним кличка: репетитор революции. Как химера, он рассыпался при свете исторического дня. По мере приближения девятьсот пятого года и часа сгущалась его таинственность и нарастал мрачный авторитет. Он должен был выявиться, должен был во что-нибудь разрешиться, - ну хоть показать револьвер из боевой дружины или дать другое вещественное доказательство своего посвящения в революцию.

И вот, в самые тревожные девятьсот пятые дни, Сергей Иваныч становится опекуном сладко и безопасно перепуганных обывателей и, зажмурившись, как кот от удовольствия, приносит достоверные сведения о неминуемом в такой-то день погроме петербургской интеллигенции. Как член дружины, он обещает прийти с браунингом, гарантируя полную безопасность (Мандельштам 2010: 235-236).

Долгое время фамилия и биографические данные этого «героя» одной из глав «Шума времени» оставались невыясненными. Впервые 
сведения о нем приведены в 1990 г. в комментариях к 2-томнику Мандельштама: Сергей Иванович Белявский (1883-1953). Учился на математическом отделении физико-математического факультета С.-Петербургского университета до 1906 г. В 1909 г. принят сверхштатным астрономом в Пулковскую обсерваторию, и почти сразу же переведен в Симеиз, заведующим филиалом обсерватории, где проработал до 1925 г. В 1937-1944 гг. был директором Пулковской обсерватории, избран членом-корреспондентом АН СССР. Окончил Рижскую гимназию (комментарий П. М. Нерлера, см.: Мандельштам 1990, 2: 395). В одном из документов (1902 г.) университетского дела указан его адрес - Николаевская ул., д. 33 (где он снимал полкомнаты, см. там же: 395) - не совпадающий со сказанным в «Шуме времени»: «...в сотых номерах Невского, за Николаевским вокзалом» (Мандельштам 2010: 234).

С помощью М. А. Котовой (приносим ей живейшую благодарность) нам удалось найти дополнительные материалы к биографии Белявского, и в сумме имеющиеся в настоящее время документы позволяют нарисовать следующую картину.

С первых лет учебы в университете Белявский определился со своей будущей профессией, занимался в научном студенческом кружке при университете и выполнил, согласно «Отчетам С.-Петербургского Императорского университета» и «Известиям Астрономического кружка С.-Петербургского университета», несколько серьезных научных работ. Уже тогда (и позднее) он отметился в науке открытием нескольких малых планет, а также комет и астероидов (некоторые из них получили название в честь первооткрывателя).

В октябре 1905 г. университет, один из очагов революционного движения, был закрыт властями, и в то же время были прекращены занятия в гимназиях и училищах. В средних учебных заведениях весь первый семестр занятия возобновлялись только спорадически, и перед учениками стоял вопрос о том, как освоить программу. Об остроте проблемы свидетельствует тот факт, что восемь из восемнадцати соучеников Мандельштама были оставлены на второй год (см.: Мец 2005: 27-29; см. также 2-е издание: Мец 2011: 
26). Мандельштаму хорошо давались предметы гуманитарного профиля, а по предметам математического цикла (алгебре, геометрии, тригонометрии) он отставал или вовсе не успевал ${ }^{1}$ и, следовательно, нуждался в репетиторе по отмеченным предметам. Заниматься с Белявским он начал не позднее середины октября по «Шуму времени» устанавливается внутренняя дата, 18 октября, когда в городах России начались погромы, и Белявский ведет разговоры на эту тему (см.: Мец 2005: 19-20; Мец 2011: 20). Репетиции продолжались, по-видимому, до самой экзаменационной сессии, т. к. еще и в феврале 1906 г. Мандельштам числился не успевающим по алгебре и тригонометрии. По «Шуму времени», Мандельштам проводил с Белявским (в группе с несколькими учениками? - ср.: «был клиентом нашего дома, как и многих других» - Мандельштам 2010: 234) относительно много времени в течение дня в октябредекабре, когда занятия в училище проводились редко (в какойто период времени приезжая на занятия из Царского Села; см.: Мец 2005: 20; Мец 2011: 20), и совместное писание «реферата» по истории о «причинах паденья Римской империи» (Мандельштам 2010: 234) было частью их общего времяпровождения, в порядке которого Белявский однажды и привел ученика к себе домой - тот «содрогнулся от густого и едкого запах жилища Сергея Иваныча» (Там же: 234). Тема реферата входила в программу курса всеобщей истории, экзамен по которому Мандельштам сдал на «отлично» 9 апреля 1906 г.

По-видимому, сближению между репетитором и учеником способствовали одинаковые политические симпатии. Как видно из «Шума времени», Белявский был «член[ом] дружины» (Там же: 236) - одной из тех, которые создавались Советом рабочих депутатов в каждом районе Петербурга для защиты от погромщиков. Можно уверенно предполагать также, что для Белявского участие в дружине было обусловлено влиянием минуты подъема революции,

1 В феврале 1906 г. не успевал по алгебре и тригонометрии (ЦГИА СПб. Ф. 176. Оп. 1. Ед. хр. 48. Л. 8; Ед. хр. 97. Л. 54), см. также: Мец 2005: 27-28; Мец 2011: 26. После занятий с Белявским отставание было преодолено, и экзамены по алгебре и геометрии весной 1906 г. были сданы успешно (см.: Мец 2005: 28; Мец 2011: 27). 
и не исключено даже, что он, как и Мандельштам в следующем году, стал на короткий период членом одной из левых партий. Таких неустойчивых называли несколько позднее «октябрьскими эсерами (эсдеками, анархистами)», чему в «Шуме времени» и соответствует прозвище «химера» (см.: там же: 233, 235, 236). Данное предположение подкрепляет справка Департамента полиции о том, что С. И. Белявский «к дознаниям по делам политического характера не привлечен и под надзором полиции не состоит»².

Университет оставался закрыт и в первой половине следующего года. Белявский 12 января 1906 г. подал прошение о выдаче выпускного свидетельства и получил его 16 января. Согласно цитированному нами в примеч. 2 документу, он получил должность «хранителя астрономического кабинета С.-Петербургского

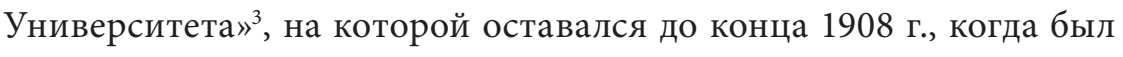
принят на «должность сверхштатного астронома Николаевской Главной Обсерватории» (т. е. Пулковской обсерватории). Поскольку название должности соответствует сказанному в «Шуме времени» «служит ассистентом на Пулковской вышке в астрономической

2 Приводим документ полностью:

Секретно.

В Управление по делам о воинской повинности.

Вследствие записки от 31 января 1909 года за № 44074 Департамент Полиции уведомляет Управление по делам о воинской повинности, что означенный в той записке Сергей Иванов Белявский к дознаниям по делам политического характера не привлечен и под надзором полиции не состоит.

Подп. за Вице-Директора <подпись неразборчива>

25 января 1910 года.

(ГАРФ. Ф. 102. Оп.108 (1910 г.). Д-во № 4. Д. 106 (литера «В»). Л. 101-123).

Справка была выдана в ответ на запрос Управления по делам о воинской повинности: «не встречается ли со стороны Департамента Полиции каких-либо препятствий к освобождению от призыва на действительную военную службу бывшего хранителя астрономического кабинета С.-Петербургского Университета, приписанного к призывному участку гор. Риги, Сергея Иванова Белявского, оставившего педагогическую службу до истечения 5-летняго обязательного срока и поступившего на должность сверхштатного астронома Николаевской Главной Обсерватории» (Там же. Л. 121).

3 Астрономический кабинет был в составе университетской обсерватории, расположенной в Петергофе. Современный адрес: Университетский пр., 28. Позднее Астрономический институт С.-Петербургского государственного университета им. В. В. Соболева. 
обсерватории» (Мандельштам 2010: 236), то встречу с ним «много позже девятьсот пятого года» (там же: 236)следует датировать началом 1909 г., когда Мандельштам находился в Петербурге4.

На этом биографические пересечения бывших репетитора и ученика заканчиваются, однако есть еще биографическое свидетельство, которое проливает некоторый свет на психологический портрет Белявского, хотя относится оно уже к более позднему времени - второй половине 1930-х гг. Мемуарист пишет:

Очень остро стоял в то время в Пулкове вопрос о новом постоянном директоре. В Пулкове кандидатуры не было, так как остались люди либо очень молодые, либо очень пожилые. Тогда в Академии наук вспомнили о сотруднике Симеизского отделения Сергее Ивановиче Белявском. Он зарекомендовал себя открывателем астероидов. По разным причинам в Академии решили, что лучшего директора искать не нужно. Белявский имел очень представительную внешность. Он был высокого роста, держался прямо и солидно, говорил медленно и с достоинством ${ }^{5}$. Его седая голова с орлиным носом производила впечатление.

Однако при назначении Белявского директором не учли или вообще не знали, что он перенес базедову болезнь, по поводу которой у него была удалена щитовидная железа. Заболевание сопровождалось тяжелыми психическими последствиями. Это, конечно, не его вина, а беда. Но из-за его «странностей», о которых знали только постоянно имевшие с ним дело люди, общение с ним было затруднено. В частности, по этой причине, когда подошел срок принятия его из кандидатов в члены партии, то это несколько лет откладывалось. Он не совершал ничего предосудительного.

\footnotetext{
4 Комментатор «Сочинений» датирует их встречу 1923 г., когда Мандельштам отдыхал в Гаспре, а Белявский был директором обсерватории в Симеизе (см.: Мандельштам 1990: 395). Однако это предположение представляется невероятным, поскольку директор Симеизской обсерватории не мог в 1923 г. говорить о себе как об ассистенте в астрономической обсерватории, да еще и Пулковской.

5 В «Шуме времени» поэт в словах «мрачный авторитет» (Мандельштам 2010: 234) чутко отразил те же черты характера Белявского.
} 
Откладывая каждый раз прием, надеялись, что дело как-то прояснится.

Вскоре после приезда в Пулково новый директор стал вызывать удивление у сотрудников тем, что ни разу не был на научных докладах, которые перестали делать в кабинете директора, а также крайней своей мелочностью. Так, лампочки для карманных фонариков и бумагу, отсчитывая каждый лист, выдавал только он сам. Чтобы узнать о каком-либо сотруднике, он никогда не требовал у него отчета или объяснения, а расспрашивал когонибудь другого. <...>

Первые признаки мании преследования у Белявского обнаружились, когда он объявил о готовившемся на него покушении через отверстие в его туалете, которое по небрежности было оставлено рабочими, производившими ремонт. Была создана специальная комиссия для расследования этого «покушения». На входной двери в комнате перед кабинетом он велел укрепить замок с электромагнитом, открывающийся нажатием кнопки на его столе. Когда кто-нибудь стучал в его дверь, то он смотрел через маленькое отверстие в двери на посетителя и, если последний не вызывал его подозрений, то он отбегал к своему столу и нажатием кнопки открывал дверь (Гневышев 1989: 354-357).

Эта грустная история, кажется нам, в чем-то перекликается с концом главы «Сергей Иваныч» в «Шуме времени»:

Если бы Сергей Иваныч превратился в чистый логарифм звездных скоростей или функцию пространства, я бы не удивился: он должен был уйти из жизни, до того он был химера (Мандельштам 2010: 236).

\section{БИБЛИОГРАФИЯ}

Гневышев М. Н. 1989. Свершения и тревоги Пулкова: (Страницы воспоминаний). - Историко-астрономические исследования. Вып. XXI. М.: Наука. С. 342-368.

Мандельштам О. Э. 1990. Соч.: В 2-х тт. Т. 2: Проза. Переводы. М.: Художественная литература. 
Мандельштам О. Э. 2010. Полн. собр. соч. и писем: В 3-х тт. Т. 2: Проза. М.: Прогресс-Плеяда.

Мец А. Г. 2005. Тенишевское училище: Взгляд на архив сквозь стекла «Шума времени». - Мец А. Г. Осип Мандельштам и его время: Анализ текстов. СПб.: Гиперион. С. 7-50.

Мец А. Г. 2011. Тенишевское училище: Взгляд на архив сквозь стекла «Шума времени». - Мец А. Г. Осип Мандельштам и его время: Анализ текстов. Издание 2-е, исправленное и дополненное. СПб.: [Б. и.]. C. 9-44. [http://www.ruthenia.ru/reprint/Mets_Mandelshtam.pdf] 